
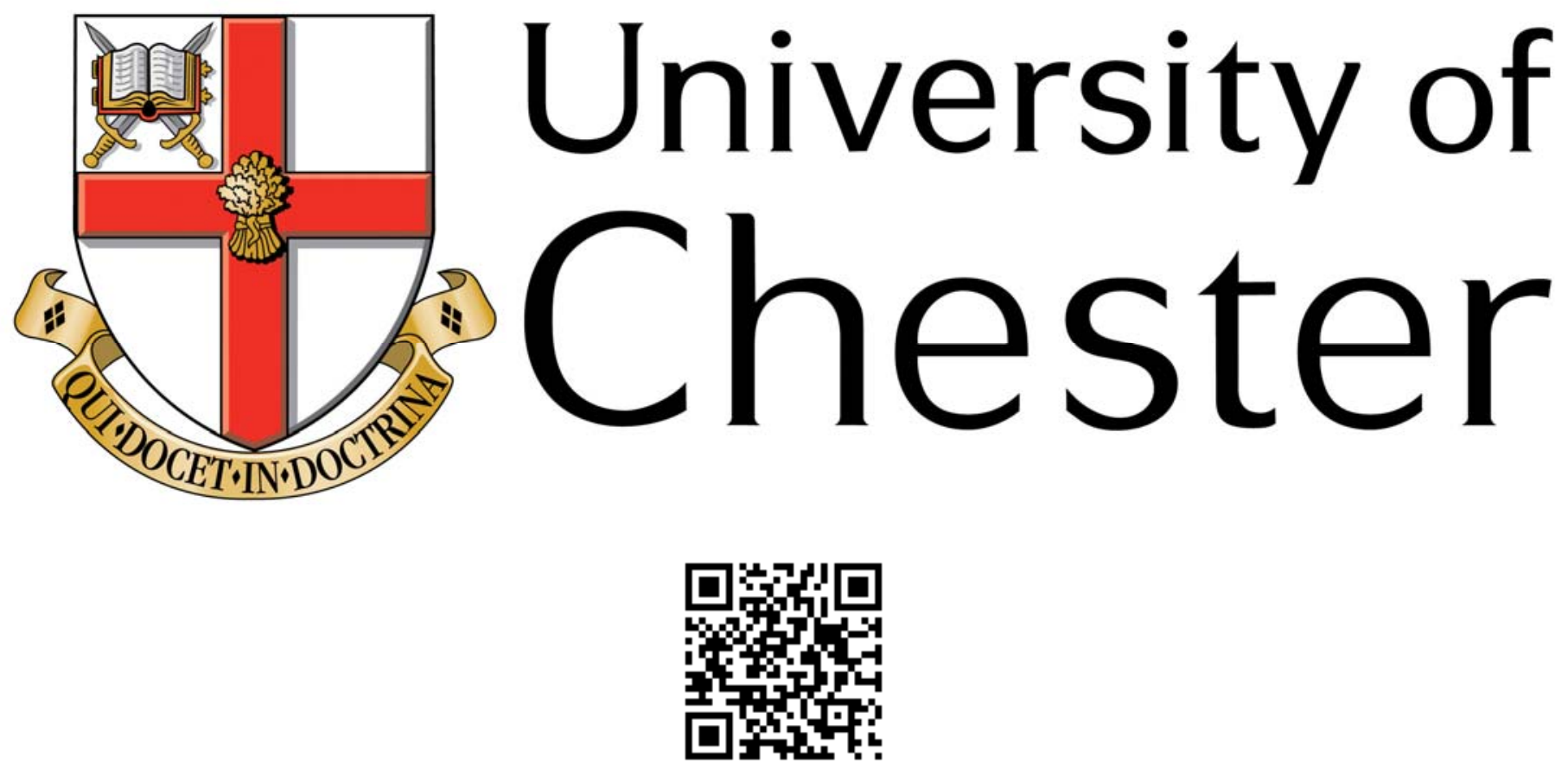

This work has been submitted to ChesterRep - the University of Chester's online research repository

\title{
http://chesterrep.openrepository.com
}

Author(s): Celia Deane-Drummond

Title: A new dawn? The Roman Catholic Church and environmental issues

Date: 1997

Originally published in: New Blackfriars

Example citation: Deane-Drummond, C. (1997). A new dawn? The Roman Catholic Church and environmental issues. New Blackfriars, 78(917/918), 316-326

Version of item: Author's post-print

Available at: http://hdl.handle.net/10034/14659 


\section{A New Dawn? The Roman Catholic Church and Environmental Issues}

\section{Celia Deane-Drummond}

\section{Introduction}

Awareness of environmental issues, seems, if anything, to be on the increase. In spite of fears that the public debate about the 'green' agenda would fade, rather like the anxiety over a threat of a nuclear holocaust, which is now far less prominent compared with the 1970s, politicians today seem even more aware of the need to include environmental concerns in their policy statements. Yet there still seems to be a gap opening up between political affirmations and cries for more radical restructuring. This gap has led to heightened tension, exemplified by the high profile displays of attachment to the land shown by characters such as Daniel Needs, alias 'Swampy', who, in January 1997 buried himself underground in an attempt to prevent an A30 'improvement' programme near Fairmile in Devon. Such actions may seem extreme, but they epitomize the dissatisfaction, especially of the young, with the ineffectiveness of politicians to make any real difference and an almost total lack of clear national transport policy. Such dissatisfaction is expressed in other ways as well: now more young people belong to voluntary environmental groups than political parties. Official jargon and teaching feels alienating for those who want to see real practical advances in the way we treat our planet. Such language also spreads into official Church documentation on other issues in a way that alienates many ordinary men and women.

\section{Incipient Response of the Roman Catholic Church}

Overall Churches have been slow to make any official responses to the environmental crisis and the Roman Catholic Church, in particular, has tended to stay on the fringe, 
rather than get involved. Environmental issues, in the immediate aftermath of Vatican 2, remained at the margins of Roman Catholic concern. The natural world was still viewed in an instrumental way, that is for the exclusive use by human beings. The 1965 Council document, Gaudium et Spes (The Church in the Modern World), aimed to connect religious and secular life, but in $\mathrm{n} .12$ still states that 'all things on earth should be related to man as their centre and crown'. In 1967 Populorum Progressio (The Development of Peoples) failed to acknowledge any destructive effects of industrialisation on the environment. Eventually, in 1988, Sollicitudo Rei Socialis (Social Concerns), to which I will return again below, includes environmental questions, but this is a long time after the responses of other Churches and politicians.

The Roman Catholic Church was initially reluctant to be full participants of the World Council of Church's meetings which addressed these issues. As 'observers' only the Roman Catholic contribution was weaker than it could have been. The Vancouver WCC Assembly in 1983 first coined the phrase, 'justice, peace and integrity of creation', emphasising the link between human justice, peace issues and environmental concerns. Germany was more keenly aware than the rest of Europe of the need to re-establish healthy relationships with the earth following the 'blood and soil' dictates of Nazism. In 1985 the German Roman Catholic Bishops' Conference issued a joint statement with the Council of the Evangelical Church entitled 'Exercising Responsibility for Creation'. This statement urged a change in attitude to animals and all creation, a change in patterns of lifestyle and consumption of resources.(1) Other positive statements on environmental issues in the 1980s were associated specifically with survival interests, such as that produced by the Justice and Peace Commission of the Catholic Church in Ghana in 1982, which linked desertification with human survival, urging the Church to preserve the land for the sake of future generations.(2) In Latin America and the Philippines there has been a 
similar recognition of the importance of environmental issues, the Guatemalan bishops in 1987 linked the cry of the poor with the cry of the land.(3) A similar statement by the Dominican Bishops was published in 1987 was entitled 'The Protection of the Land is a Condition of Survival'. This text is quoted in Renewing the Earth, published by CAFOD in 1991. It is ironical, perhaps, that in Britain it is the Catholic overseas development agency that has become more sensitive to environmental issues, even though the introduction of these concerns arrives relatively late into the agenda of liberation theology.(4) A pastoral letter by the Philippine Roman Catholic Church published in 1988 addressed environmental issues which emerged from the heart felt concern of ordinary people. 'What is Happening to Our Beautiful Land?' is a cry of people, especially women, sensitised to the 'beauty and pain' of the earth.(5) The soils are washed away, again giving real threat to survival and a deep remorse, 'God, who created this beautiful land, will hold us responsible for plundering it and leaving it desolate'.(6)

The WCC meeting in 1986 in Manila marked an approach to human labour which was more environmentally sensitive. Cardinal Sin spoke vigorously about the harmful social and environmental effects of the Protestant work ethic, especially in relation to a lack of workers' rights in South East Asia and other parts of the world.(7) At the 1989 WCC conference in Basle on Justice and Peace, Roman Catholics were participants, rather than observers, and took a much more active part, though the contingent from Britain was very small. Yet while the European Catholic Bishops' conference sponsored the Basle meeting, there was still no official sponsorship by the Vatican of the 1990 World Convocation on Justice, Peace and the Integrity of Creation at Seoul.

Sollicitudo Rei Socialis firstly urges respect for the natural world and a deeper awareness of the needs of all creatures, rather than human grasping out of economic necessity. 
Secondly, the non renewable nature of resources forces us to consider the effects on future generations. Such ideas have surfaced in a brief statement on the 'environmental common good' in The Common Good, published by the Catholic Bishops' Conference of England and Wales in 1996. A third consideration mentioned in Sollicitudo is the public health risks associated with industrialisation. The Pope begins to speak of the environmental crisis as an important moral issue, which he develops further in his 1990 World Day of Peace Message, 'Peace with God the Creator; Peace with All Creation'.(8)

The Papal statement raises a number of specific environmental issues. First, the indiscriminate application of advances of science and technology which has resulted in global pollution of common resources. Second, the further self destruction from an indiscriminate genetic manipulation, which, left unchecked, leads to the rejection of respect for life and respect for the integrity of creation or its 'ordering'. He identifies greed and selfishness at the root of the crisis, both at an individual and corporate level, calling for an 'internationally coordinated approach to the management of the earth's goods'. The nature of environmental problems are such that while international cooperation is essential, this 'does not lessen the responsibility of each individual State'.(9) He argues that the needs of the most vulnerable in each society need protection, every citizen has a right to a safe environment. The structural causes of poverty have to be addressed at the same time, along with alleviation of the menace of war. He believes that modern society needs to examine its current attachment to consumerism and instant gratification. He states starkly that 'An education in ecological responsibility is urgent, responsibility for oneself, for others, for the earth'.(10) He believes that we need to recognise the aesthetic value of creation which has 'deep restorative power', any urban planning has to be sensitive to the natural world. 
The Asian Bishop's Conference has taken this statement to heart, urging their Catholic counterparts to engage in an 'ecological apostolate'.(11) In the aftermath of the Rio Summit of 1991, the time seems ripe for a more full hearted response to environmental issues by the Catholic Church.

\section{Emerging Contemporary Catholic Theologies of Creation}

In this brief section I hope to show some of the ways in which Catholic theologians have begun to incorporate environmental issues into their theological reflection. By so doing I hope to indicate ways in which theology can contribute to the debate and how ecological issues could, in practice, become integrated into theological education programmes. In the past the heavy concentration on history by theologians has spawned a counter reaction in a variety of creation spiritualities, such as those proposed by Matthew Fox, which stressed the goodness of creation as the 'original blessing'.(12) Such theologians latched onto the popular search for a deeper unity with the natural world, that has become characteristic of a Western culture alienated from the environment. Nonetheless, his theology was still weak in its recognition of any human sinfulness and/or any practical environmental issues.

The question now is, can we recover elements in the tradition which point to a more fruitful relationship with the earth by exploring the writings of those from earlier Christian communities, such as those of St. Francis(13); or the more mystical writing of Hildegard of Bingen(14); or the connectedness with the land in the writings of the Cistercians(15), or the poetic sensitivity of the Celtic Christians.(16) The key feature in each case is the recovery of a theology that stresses God's immanence, but without sliding into pantheism. Celtic Christianity, in particular, has become increasingly popular in Britain. While one of the reasons for this may be its seeming lack of organisational constraints, another reason may be its affinity with the land, a sense that this marked the cultural beginnings of 
Christian Britain. It seems to me that it is unlikely that we can recover the unselfconscious approach to the natural world that was characteristic of Celtic Christians, but a Celtic sensibility can still help to change our attitude so that we are more sensitive to the effects of our actions on the planet. Celtic Christians were remarkably practical in their approach to the environment around them, as long as we stay in tune with this deep pragmatism we will not be lost in dreams of a golden age.

Sean McDonagh writes out of experience of work in the Philippines and his approach brings with it a practical urgency that comes from a deep knowledge of a people whose ecological interests are a matter of survival.(17) His work contrasts with many other creation theologies as he seeks to integrate practical issues and takes a broad liberation theology perspective.

It seems to me quite possible that the reluctance of the Roman Catholic Church, especially in Europe, to engage in environmental issues has stemmed from three anxieties. First, the anxiety that popular creation spiritualities, supported by feminist theology, would encourage disaffiliation with the Church and a return to NeoPaganism. Secondly, the official anxiety about liberation theology, which still carries the stigma that it is attached to Marxist ideology. Thirdly, the false belief that scientists are the ones who can find solutions to environmental problems, so that it is not an issue for proper consideration by the Church.

More traditional theologians, such as von Balthasar, who have published masterly works on creation theology, have done so with no reference at all to practical ecological issues, or even to non-human creation as such.(18) While von Balthasar highlights the Mass as the place where the Creator Spirit makes salvation history, it is undoubtedly an anthropocentric focus which prevails. This contrasts with Orthodox theologians, such as John Zizioulas who, while he still highlights the place of humanity, stresses its relationship to all creation.(19) He argues that the drive towards freedom in humanity becomes 
accessible to all creation through the Eucharist. The world becomes sacred through its relationship with God, which leads to a profound sense of human responsibility.

A cosmic approach is also rooted in scripture, as Robert Murray suggests, the Old Testament covenant is a Cosmic covenant.(20) The New Testament also points to human solidarity with the earth, so that Christians are called to preserve the earth because it is the 'dwelling place of the Word of God'.(21) McCarthy believes that we need to recognise the autonomy of creation. Is this autonomy compatible with the seeming salvific dependence of creation on humanity, as suggested by Zizioulas? I believe that it is, but it is a unity forged though 'groaning', all creation groans, including humanity who hesitates at a deeper metanoia and unselfish responsibility for all creation.

\section{Environmental Challenges Facing the Church in Britain}

What are the environmental issues most relevant for consideration by the Church today? In this section I intend to offer some suggestions as to key areas which require further consideration and debate before arriving at some working conclusions. This is relevant not just for the official Church, but also individuals concerned to engage in environmental problems for educational or other purposes. This list, nonetheless, is not intended to be exhaustive and provides a starting point for further discussion. Many of the areas I mention are interconnected, but I have tried to begin with more readily accessible problems before moving to technical issues.

\section{Conservation}

The idea of conservation of places of natural beauty is rooted in British culture through organisations such as the National Trust, National Heritage etc. It is seemingly less threatening an approach compared with the more 'radical green' protesters and attracts 
those from any political persuasion. Organisations such as these operate on a philosophy of preservation of what is there already. In the aftermath of industrial mining or other development there is an increasing pressure to 'restore' the land to its original condition. Debates in this area include: How far is restoration ever really possible? Does the 'unnaturalness' of many of our parks, long since denuded of their original ancient forest, make them any less the subject for conservation? How can we encourage the preservation of 'wilderness' areas without restricting access to all but the elite? What is an appropriate response to projects which aim to increase forest cover, such as community forest development?

\section{Resources}

Resources fall into two categories; those that are renewable and non-renewable. The questions which arise in this instance include; Are we making best use of renewable resources? How are we seeking to minimise the loss of non-renewable resources, such as gas and coal? Nuclear power was initially heralded as the answer to our energy needs, but the cost of maintenance of plants and the safe disposal of waste offsets the initial advantages. Ever since Chernobyl the public reaction to nuclear power has become more ambivalent. In many parts of the world water is also counted as a scarce resource, perhaps in Britain we will find ourselves under increasing pressure to minimise waste. The use of energy generates pollution of common resources of land, air and water. It is all too easy to believe that my small amount of pollution will not make much difference, either positively or negatively. I will return to the questions arising out of community and individual ethics below.

\section{Biodiversity}

While Britain does not suffer from the same degree of species loss as that experienced in 
tropical rain forests, the issue of biodiversity is still important to consider. The 'reclamation' of swamp areas totally changes their ecological make up, in some cases resulting in the loss of rare species. How do we balance the economic interests of humans with the survival interests of particular species? What is the value of those species which are seemingly less appealing to humans, especially lower in the evolutionary tree?

\section{$4 \quad$ Animal welfare}

This issue is definitely one most Britons are familiar with given the common attachment to pets and a strong national sense that cruelty to animals is wrong. Animal rights protesters may be taking an extreme position for many, but they have raised important issues associated with factory farming. Once animals are seen simply as means to increase profit, rather than creatures created and loved by God, all respect is lost and they become part of a mechanised means of production. Philosophers and ethicists such as Stephen Clark believe that vegetarianism is the only real option for those who have a genuine respect for animals.(22) Theologian, Andrew Linzey, takes a similar view from a Protestant perspective.(23) But is a Catholic response to animal welfare necessarily vegetarianism, even if we do not need to eat meat for our survival? Whether we believe animals have souls or not, some concise theological debate on this issue from a Catholic perspective seems pertinent.(24)

\section{$5 \quad$ Biotechnology}

Although at first sight this issue seems more removed from classic consideration of environmental issues, I include it here because I believe that biotechnology gives humanity power that can lead to enormous environmental impact. While classic breeding methods have also generated changes in the landscape, biotechnology promises to deliver a plethora of species which have had their genetic make up altered so that they are 
transgenic hybrids. All kinds of transformations are possible, including genes for herbicide resistance custom made for each species, insertion of the capacity for antibiotic production, insertion of the capacity for hormone production and so on. The patents owned by limited companies gives them enormous power over the farming community, who are trying to work within limited budgets.(25) While the social effects of this technology is unlikely to be as stark as in the Third World, there is a shift towards a loss in diversity of species to those that are genetically engineered with associated risks of disease. How should the Church respond to these shifts in power, including related issues such as transgenic organ transplants? What is the response to cloning of animals, this possibility is now a reality with the first sheep, alias 'Dolly' to be cloned from its mother in Edinburgh. Up until this time the common assumption was that cloning was only possible for organisms lower down the evolutionary tree. The possibility that this could apply to humans is horrifying, legal restraints may not be sufficient or apply at an international level.(26) The genetic testing of humans was only possible after techniques had been developed in micro-organisms, plants and animals. What are the social and ethical implications of this new technology? Such issues reinforce the interconnectedness of all living things and alert us to future problems and possibilities.

\section{Cooperate/individual ethics}

Much of the pollution and exhaustion of common resources comes through industrialisation. How far do corporations take into account environmental issues and how can the Church encourage deeper engagement? It seems clear that energy saving solutions link with those which help conserve the environment. While multinational companies have been the subject of severe criticism from campaign groups, in practice it is the smaller firms who cannot afford the technology for pollutant control. For those companies struggling with limited budgets BATNEC (Best available technology not 
involving excessive cost) becomes CATNIP (Cheapest available technology not involving prosecution). Even then legislation is not necessarily the most effective means of restraint, in economic terms prosecution may be cheaper than the cost of installing appropriate pollutant control mechanisms. Public pressure for companies to be more environmentally accountable is perhaps one way there can be a shift in cooperate ethos. Could the Church set an example in undertaking an ecological audit? How far do Churches put their own house in order by making sure energy consumption and pollution is kept at a minimum? How far can the Church make recommendations to changes in individual lifestyle, such as use of cars etc., while still respecting the freedom of choice of each person?

\section{Environmental justice}

Those poor communities living at the 'underside' of society are more likely to live in heavily polluted industrial areas. They are often the victims of environmental injustice. By this I mean that they experience what lawyers call a 'nuisance', though in reality the effects are more severe than this implies and it results in the deprivation of good health, the contamination of land and other related factors such as 'noise' pollution. Multiparty legal action against companies who act improperly is becoming more widespread and it seems to me that this is a trend that is set to continue. A related issue is the detrimental effects on health of those who live near nuclear power stations. What is the Church's response to this suffering? There are many others who suffer in silence, too alienated from society to seek legal aid. Their right to a clean and safe environment needs to be addressed.

\section{Economics/policy development}

The complex nexus of relationships between policy, economics, environment and development is daunting for most scholars, let alone ordinary citizens. The pressures posed on the environment are felt in socialist or market economies and seem an inevitable 
result of growth. There are some who argue for zero growth policy, but even in this instance, some environmental damage is inevitable. The Church's response to environmental issues needs to take into account economic pressures, but recognise the moral and spiritual root of many economic problems. But it is all too easy for theologians to slip into moral/spiritual language in a judgmental way without sufficient wrestling with the problems themselves. The move towards privatisation of public amenities has tended to stifle a national consideration of problems, such as transport policy, access to water and so on.

\section{$9 \quad$ Global issues}

In Britain the threat of war seems remote compared with other countries. Yet public expenditure on armaments is in excess of almost all other public budgets. The potential environmental damage caused by military action stays on the fringe of the agenda. Genetic engineering of microbes, plants, animals and humans promises ever more sophisticated weapons for biological warfare.

Global climate change caused by the greenhouse effect threatens the very existence of some island communities. Climate changes may start to have an increasing effect on the British landscape through changes in rainfall and so on. Population issues also seem more remote in a nation that is not facing a population explosion as in the poorer communities of the world. Yet this issue raises other ones which are connected with social and economic justice and justice for women in particular. The pressure that the increase in population places on the environment has to be considered, especially for a Church that seems still set in its condemnation of birth control, regardless of circumstances.

The needs of the global community have to be taken into account when following particular 
recommendations, such as Agenda 21 proposed at the Rio Summit in 1991. There are some signs that the Church in Britain at the local level is taking Agenda 21 to heart through Inter-Church discussion groups etc. and the work of development agencies at the parish level. The Catholic Church, in particular, is in a good position to encourage global cooperation towards positive environmental projects through its international networks.

\section{Practical Projects and Education Strategy}

The introduction of environmental issues into the school curriculum is now far more widespread than it was even a decade ago. Less common is the introduction of ethical and religious questions which surface through a discussion of these issues. A greater environmental awareness included in education programmes of the Church would serve to foster a senses of relevance and connect with the needs of young people. Moreover, education needs to encourage a holistic examination of problems, rather like the ancient wisdom of the philosophers. The unity of the Catholic Church with its sacramental liturgical life lends itself to a holistic approach. Environmental problems encourage a greater global awareness by young people, fostering a deeper understanding between peoples of different cultures and religions. Pupils can experience the aesthetic value of creation in Britain, at least for the time being. The very practical nature of environmental problems means that it can become a subject for action and discussion at all age and ability levels.

Many other Churches have taken practical leads in developing programmes which foster environmental awareness, as well as having positive environmental outcomes. One such project is the Churchyards Project, designed to preserve wildlife in the Churchyards across Britain.(27) The report Faith in the Countryside, shows a similar respect for our natural landscape.(28) In 1990 the Greek Orthodox Church began an organic farming monastic project known as the Ormelia Project on land which had at one time been damaged by the 
use of pesticides.(29)

Is there really a new dawn in the Catholic Church? We do not have the luxury to be cautious for much longer. If we have listened to the Catholic response in other parts of the globe, consideration of environmental issues amounts to their physical survival. While we are not in such immediate danger in the Western world, responsible action needs to begin at home if we are to retain something of the beauty of our land for ourselves and future generations.

1 'Joint Church Statement on Ecology', cited in D. Gosling, A New Earth (CCBI, 1992), p. 20.

2 'Desertification of Ghana', Justice and Peace Commission of the Catholic Church of Ghana, September, 1982.

3 'The Cry for Land', pastoral letter by the Guatemalan Bishops' Conference, 1987, Newsletter 4 (1988), p. 4.

4 See C. Deane-Drummond, 'Development and Environment: in Dialogue with Liberation Theology', New Blackfriars, Vol 78. (June 1997), pp. 279-289.

5 See D.Gosling, op. cit., pp. 53-54.

6 Full text appears in Appendix 2 in S. McDonagh, The Greening of the Church (Geoffrey Chapman, 1990), pp 206-216, see p. 208.

7 Ibid., p. 211.

8 Full text reprinted in Theology in Green, Issue 3 (1992), pp. 19-27.

9 Ibid, p. 23.

10 Ibid, p. 25.

11 'Love for Creation: An Asian Response to the Environmental Crisis', Catholic International, June 1993, pp. 270.

12 M. Fox, Original Blessing (Bear and Co., 1983)

13 See, for example, R.D. Sorrell, St Francis of Assist and Nature, Oxford University Press, 1988.

$14 \mathrm{H}$. Stanton,' Vividitas: The Greeness of Hildegaard of Bingen, Theology in Green, Vol. 4 , issue 3 (1994), pp. 26-30.

15 J. McCarthy, 'Cistercians and Land: A Geography of Salvation', Theology in Green, Vol. 4, issue 3 (1994), pp. 5-18.

16 C. Deane-Drummond, 'Recalling the Dream: Celtic Spirituality and Ecological Consciousness', Theology in Green, Issue 7 (July 1993), pp. 32-28.

17 See, especially, S. McDonagh, The Greening of the Church, op. cit; Passion for the Earth (Geoffrey Chapman, 1994).

18 H.von Balthasar, Explorations in Theology III: Creator Spirit (Ignatius Press, 1993)

19 J. Zizioulas, 'Preserving God's Creation, Part 3', King's Theological Review, Vol. 13, issue 1 (1990), pp. 1-5.

20 R. Murray, The Cosmic Covenant (Sheed and Ward, 1992)

21 J. McCarthy, 'The Expectant Groaning of Creation: Cosmic Redemption in Romans 8: 
19-22', Theology in Green, Vol. 4, issue 1 (1994), pp. 24-34.

22 S. Clark, How to Think About the Earth (Mowbray, 1994).

23 A. Linzey, Animal Theology (SCM Press, 1994)

24 M. Atkins, 'Could There be Squirrels in Heaven?', Theology in Green, Vol. 4 (October 1992), pp. 17-27.

25 C. Deane-Drummond, Theology and Biotechnology: Implications for a New Science (Geoffrey Chapman, 1997), in press.

26 See, 'Home News: Will Cloned Sheep Pave the Way for Humans?', The Tablet, 1 March (1997), p. 304. The technique as applied to humans was condemned in Donum Vitae, Congregation for the Doctrine of the Faith (1987).

27 'The Living Churchyards', A DIY Information Pack (Church and Conservation Project, 1987).

28 ACORA, Faith in the Countryside (Churchman Publishing Ltd, 1990)

29 C. Deane-Drummond, A Handbook in Theology and Ecology (SCM Press, 1996), pp. 13-14. 